\title{
Biological Weapons and International Law
}

\author{
Dr. Abeer Al Alubaidi \\ Taif University \\ Taif 26571, Saudi Arabia
}

\begin{abstract}
Belligerents have used biological weapons since antiquity, and even as late as World War II, after the League of Nations had adopted its 1925Protocol against chemical or biological warfare. During World War II, Japanese forces used germ warfare on China, and the United States was developing its own biological weapons. In 1969, President Nixon officially ended the United States' biological weapons program, and in 1990, the US Congress adopted Public Law No. 101-298, which outlawed the production, acquisition, stockpiling and retention of biological weapons by any organization or individual within the United States, and in 1972, the United Nations adopted the Biological Weapons Convention. However, the implementing of decrees and legislation about prohibiting biological weapons has usually been more difficult than promulgation. In 1975, for instance, the US Senate held hearings about the CIA's continued inventories of toxins. In 2001, US rejection of the composite compliance protocol that the Ad Hoc Group of the Biological Weapons Convention was formulating halted the Group's negotiations concerning that protocol. As a result, the Biological Weapons Convention now features Confidence Building Measures (CBMs) aimed at encouraging States Parties' eventual implementation, rather than a formal protocol.
\end{abstract}

Keywords: Biological weapons, United Nations, Biological Weapons Convention, implementation, Ad Hoc Group, Composite Protocol, Confidence Building Measures.

\section{Historical Background and Initial International Law}

Warring human groups have used biological weapons, in the form of diseased live or dead persons, or animal carcasses, even before humans were aware of the existence of bacteria, viruses and toxins. This sort of primitive germ warfare occurred during Antiquity. throughout the Middle Ages, and in the Americas, during the eighteenth and nineteenth centuries. British forces, for instance, used the Smallpox virus against their Native American adversaries during the French and Indian War of 1754-1767. During the American Revolution, the British army sent Smallpox-infected persons behind Continental lines in an attempt to start an epidemic within the Continental Army. Both sides during the American Civil War of 1861-1865 used animal carcasses as water pollutants (Schmelzer, 2013: 42\& 44).

States continued to develop biological weapons for modern warfare as well. By the end of World War II, all of the major powers had developed methods both for the mass-production and the distribution of weaponized microorganisms. In 1943, for example, under orders from President Franklin D. Roosevelt, the US developed a munitions facility for the mass production of Bacillus Anthracis, the Anthrax bacillus. The US continued developing biological weapons up until 1969, the year President Nixon declared an end to the US's germ warfare program. Another World War II combatant, Japan, had actually used biological weapons in China, conducting experiments on thousands of farmers and prisoners there, and attacking Chinese cities and military forces withBacillus Anthracis, Vibrio Cholerae (the Cholera virus), and Yersinia Pestis (Plague). Japanese troops contaminated water supplies with these agents, fired them from aircraft, and disseminated them by means of fleas that had ingested the blood of plague-infected rats. (Schmelzer, 2013: 42\& 46).

Nonetheless, by the latter half of the nineteenth century, growing realization of the devastation that both chemical and biological weapons could cause engendered international legislation condemning both kinds of weapons. Early prohibitive legislation included the Brussels Declaration of 1874, which forbade the use of poison or poisoned weapons in combat, and the Hague Conventions of 1899 and 1907, which barred belligerents from using projectiles carrying payloads of asphyxiating gas (Schmelzer, 2013: 44). Subsequently, the League of Nations and the United Nations were to adopt legislation prohibiting the use, and then the production, possession and stockpiling of weaponized biological agents.

The League of Nations' internationally-binding legislative document covering the use of biological weapons in wartime was the Protocol for the Prohibition of the Use in War of Asphyxiating, Poisonous or Other Gases, and of Bacteriological Methods of Warfare, signed at Geneva on June 17, 1925. The League of Nations had adopted this Protocol within the framework of the Geneva Conference for the Supervision of the International Traffic in Arms of that year. (US Department of State: 2002). The backdrop for that conference had been the widespread use of chemical weapons during the First World War, and the conviction on the part of a growing number of states that it 
was necessary to ban the wartime use of biological weapons. At the 1925 Geneva Conference, the US had initially called for the prohibition of the export of gases for wartime use.

France gave the 1925 Protocol its character by advocating outlawing the use of gas as a combat weapon. Poland called for extending that prohibition to the use of bacteriological, or biological weapons in warfare. Thus, when the 1925 Conference adopted the Protocol, it included the provision against the use of biological weapons in wartime situations (US Department of State: 2002). The Protocol became effective in 1928, and is quoted in full below:

The Undersigned Plenipotentiaries, in the name of their respective Governments:

Whereas the use in war of asphyxiating, poisonous or other gases, and of all analogous liquids, materials or devices, has been justly condemned by the general opinion of the civilized world; and

Whereas the prohibition of such use has been declared in Treaties to which the majority of Powers of the World are Parties; and

To the end that this prohibition shall be universally accepted as a part of International Law, binding alike the conscience and the practice of nations;

Declare:

That the High Contracting Parties, so far as they are not already Parties to Treaties prohibiting such use, accept this prohibition, agree to extend this prohibition to the use of bacteriological methods of warfare and agree to be bound as between themselves according to the terms of this declaration.

The High Contracting Parties will exert every effort to induce other States to accede to the present Protocol. Such accession will be notified to the Government of the French Republic, and by the latter to all signatory and acceding Powers, and will take effect on the date of the notification by the Government of the French Republic.

The present Protocol, of which the French and English texts are both authentic, shall be ratified as soon as possible. It shall bear todays date.

The ratifications of the present Protocol shall be addressed to the Government of the French Republic, which will at once notify the deposit of such ratification to each of the signatory and acceding Powers.

The instruments of ratification of and accession to the present Protocol will remain deposited in the archives of the Government of the French Republic.

The present Protocol will come into force for each signatory Power as from the date of deposit of its ratification, and, from that moment, each Power will be bound as regards other powers which have already deposited their ratifications.

IN WITNESS WHEREOF the Plenipotentiaries have signed the present Protocol.

DONE at Geneva in a single copy, this seventeenth day of June, One Thousand Nine Hundred and Twenty-Five (League of Nations: 1925).

Debate was to surround this Protocol, and subsequent multilateral legislation covering germ warfare concerning three issues. The first of these was the extent to which such treaties and conventions had actually been incorporated into the canon of international law. The second, and related question was that of the extent to which states considered these agreements binding. The third issue was that of perceived weaknesses within the language of such agreements. Indeed, there has been debate concerning the very definition of a biological weapon. Richard A. Falk, Professor Emeritus of International Law and Practice at Princeton University, points out that the 1925 Protocol failed to define precisely the agents to be included within that category. To him, this omission was not surprising since prior to the formulation of the Protocol itself, no prohibitive tradition had been established regarding the use of biological agents in warfare(Falk, 1986: p. 22).

The United Nations General Assembly Resolution 2603A, enacted in 1969 defined biological weapons as “... living organisms,..., or infective material derived from them - which are intended to cause disease or death in man, animals or plants, and which depend for their effects on their ability to multiply in the person, animal or plant attacked." Professor Falk considered this definition limited, because it did not include inanimate substances derived from organisms. Cobra venom, for instance, was considered a chemical weapon and was, therefore, banned from use in combat under the 1925 Protocol. In other instances, however, this venom and other biologically-derived substances might avoid being banned from use in wartime because of legislative failure to define them as biological weapons. (Falk,1986: 22, \& 22, n. 19).

The main distinction between biological and chemical weapons is that weaponized biological agents are living organisms, such as bacteria, viruses, rickettsia, fungi or protozoans, or toxins derived from these or other organisms, that can enter a living body by means of injection, ingestion, or inhalation. 
As liquid contaminants of water, air, or soil, as bomb-dropped aerosols, or if disseminated by a vector, such as a mosquito, these substances can wreak massive damage on humans, animals and plants.

Weaponized organisms can also widen this damage through their own reproductive capabilities. Chemical weapons can cause similar damage, but they are not organic derivatives, are inanimate themselves, and therefore, cannot reproduce. The Biological Weapons Anti-Terrorism Act of 1989, or S. 993, on which the US Senate held hearings during that year, was to implement the United Nations Biological Weapons Convention of 1975 in the United States by prohibiting the possession or development of germ warfare agents and devices within the United States, and by authorizing the punishment of those within the United States who helped foreign powers acquire such weapons (See below). § 178 of his legislation defined biological defined biological weapons as follows:

As used in this chapter,

(1) the term 'biological agent' means any micro-organism, virus or infectious substance, capable of causing -

(A) death, disease, or other biological malfunction in a human, an animal, a plant, or another living organism;

(B) deterioration of food, water, equipment, supplies or material of any kind; or

(C) deleterious alteration of the environment;

(2) the term 'toxin' means, whatever its origin or method of production -

(A) any poisonous substance produced by a living organism; or

(B) any poisonous isomer, hoimolog, or derivative of such a substance;

(3)the term 'delivery system' means -

(A) any apparatus, equipment, device or means of delivery specifically designed to deliver or disseminate an agent, toxin or vector or

(B) any vector;

(4) the term 'vector' means a living organism capable of carrying an agent or toxin to a host. (United States Senate, 1989: Chapt. 10, § 178, I[ 1-4).

Regarding the issue of judging whether or not an agreement could be considered part of the body of international law, Ambassador Thomas Graham Jr., a former senior US diplomat who had participated in negotiations regarding arms control and non-proliferation agreements between 1970 and 1997, argued that even as early as 1943, it was valid to consider the 1925 Geneva Protocol part of international law, because that Protocol had been in force for fifteen years and had forty-two states parties. Moreover, even though the US did not actually ratify the Protocol until 1975, in 1943, President Franklin D. Roosevelt had stated that the general opinion of civilized humanity had outlawed the use of the weapons that the Protocol had named, and that the US would never be the first state to use them. Therefore, Graham, concluded that, as of 1943, the Geneva Protocol had met the two criteria required for inclusion within the body of international law: 1) being in effect for a sufficient time period and having garnered a substantial number of States Parties; and 2) obtaining a national policy statement from President Roosevelt to the effect that civilized humanity had outlawed the use of chemical and biological weapons (Graham, 2002: 2325). However, some States Parties, such as the UK, France and the Soviet Union, ratified or acceded to the Protocol with a reservation allowing them to retaliate in kind if adversaries or the allies thereof used chemical or biological weapons against them first (US Department of State: 2002).

Regarding weakness of language, Falk pointed out that while the Protocol forbade the use of biological materielas a combat weapon, it did not prohibit the development and possession of, or research on, the use of such materiel. He maintained that once a state had developed an inventory of biological substances that state was unlikely to refrain from military research concerning those agents. Regarding weaknesses in the language of United Nations General Assembly Resolution 2603A, Falk argued that General Assembly resolutions are not legally binding upon States Parties. He also mentioneda major reality about the regime governing international relations which weakened the Resolution. Specifically, he pointed out that then as now, that regime contained no mechanism for policing a state's abuse of the law, and therefore, geopolitical realities allowed sovereign states considerable leverage in interpreting international law (Falk, 1986: $22 \& 23$ ).

\section{The Biological Weapons Convention of 1972 and Implementation Questions}

The United Nations' adoption of the Convention on the Prohibition of the Development, Production, and Stockpiling of Bacteriological (Biological) and Toxin Weapons and on their Destructionin 1972, effective in 1975, represented a further attempt to address the linguistic weaknesses in the 1925 Protocol. Ambassador Graham 44 
maintained that this Convention, like the 1925 Protocol, met the criteria required for inclusion within the corpus of international law, because of what he called the precedents of state practice.

To him, these state practices included the fact that, as of 2002, the year of the publication of his article, no state had officially used biological weapons in recent decades. Secondly, he noted that the Biological Weapons Convention of 1972 had been in effect for more than twenty-five years as of 2002. Finally, he mentioned that President Nixon had announced the US's unilateral renunciation of biological weapons in 1969, and that no state had acknowledged possessing them as of 2002(Graham, 2002: 2325).

The Preamble to the Convention praised the contribution of the 1925 Geneva Protocol to global recognition of the horrors of war, and reiterated the importance of worldwide adherence to the Protocol's provisions. However, the Convention went farther than the Protocol in terms of injunctions directed at States Parties. Article I of the Convention, for instance, prescribed that each state party must endeavor never to "...develop, produce, stockpile or otherwise acquire or retain..."types and/or quantities of "microbial or other biological agents or toxins... that have no justification for prophylactic, protective or other peaceful purposes" (United Nations, 1972: Art. I).Article I also forbade the acquisition, production, development or stockpiling of equipment and weaponry meant for wartime delivery of biological substances. Article II required each State Party either to destroy its biological war materiel, or to divert it towards peaceful purposes Article III enjoined each State Party against assisting any other state, group of states, or international organization in the development or general acquisition of biological substances for wartime purposes, and Article IV required each State Party to take measures which would prevent and prohibit within its own territory or jurisdiction the development, acquisition, or retention of biological war materiel and delivery systems therefore (United Nations, 1972: Arts. I-IV).

Articles V,VI, and X contained provisions concerning the manner in which States Parties were to interact with each other regarding the eradication of biological war weaponry. Article V urged these States Parties to cooperate, independently or within the framework of the United Nations, in resolving any problems that arose regarding the implementation of the Convention's provisions. Article VI granted any state party finding another state party to be contravening the Convention to file a well-documented complaint before the United Nations Security Council, and required States Parties to cooperate with the United Nations Security Council's investigations of such breaches. Article X urged States Parties to cooperate both among themselves and with other states in the exchange of technological information and other assistance geared towards the use of microbial and biological agents, including toxins, for peaceful purposes (United Nations, 1972: Arts. V, VI \& X).

\subsection{The Implementation Issue}

Richard Falk lauded the Convention for asserting that in order to prevent the use of biological substances as weapons, States Parties would have to institute an international regime which would enjoin states to make efforts to destroy all biological material except that which could be used for peaceful purposes. At the same time, Falk maintained that it might be difficult for a multilateral regime to distinguish between the potential military purposes of a given state's supply of biological substances, and its "prophylactic, protective, and other peaceful purposes" (United Nations, 1972: Art. I).Falk also pointed out that Article II, which enjoins a State Party to destroy or reorient its supply of biological material towards peaceful purposes, gives that state excessive, discretion in preventing the translation of protective functions that biological substances can perform into military ones. (Falk, 1986: 26).

Falk also stated that the Convention had failed to specify means for enforcement of its provisions, since violations would be difficult to verify. (The Cold War atmosphere of distrust between US and the Soviet Union made verification of contravention charges all the more difficult in 1986.)In addition, despite the Nixon Administration's renunciation of the US's biological weapons program in 1969, the US Government had been accelerating its support for experimentation on, and the development of, biological agents for medical purposes. Again, such an ostensibly civilian program could easily become part of a larger, militarily-oriented one. In fact, Falk mentioned that the US. Government had, in part, been justifying these experiments under the claim that the Soviet Union was conducting research for the development of a biological weapons arsenal which would allow Moscow to attain first-strike capability in the biological, if not in the nuclear, realm. As an illustration of this US claim, Falk referred to an explosion which occurred at a biological weapons facility in the Soviet city of Sverdlovsk in 1979, releasing anthrax spores which killed 1,000 soldiers and civilians (Falk, 1986: 27, \& 27, n. 50).

There was also the issue of the use of biological weapons in covert operations.In1975, the Senate Committee to Study Governmental Operations with Respect to Intelligence Activities held hearings concerning the Central Intelligence Agency (CIA's) unauthorized storage and retention of eight milligrams of cobra venom and eleven grams of shellfish toxin. Since these hearings took place after President Nixon's 1969 memorandum renouncing the US's use of biological weapons, the issue had Constitutional ramifications. At the hearing, Senator Walter Mondale (D. MN) questioned Nathan Gordon, Chief, at the time, of the Chemistry Branch of the CIA's Technical Services 
Division, about the Agency's failure to carry out the President's order. Nathan Gordon answered by declaring that the CIA was not a military organization, and therefore, was outside of the 1969 memorandum's scope.

During his lengthy testimony at the hearing, CIA Director William Colby emphasized that it was necessary for the Agency to continue to retain its biological agents, and neither he nor other ranking CIA officials acknowledged any legal barriers against such retention. In fact, most of the senators who questioned the CIA officials at the hearing focused their concern on the Agency's disregard for President Nixon's 1969 Memorandum, a breach of US law, rather than on violation of the Biological Weapons Convention, an instrument of international law. However, Senator Frank Church (D. ID) did state that in retaining this biological material, the CIA was breaching both domestic and international law(Falk, 1986:28, 29\& 30).

As stated above, Article IV of the Convention on the Prohibition of the Development, Production, and Stockpiling of Bacteriological (Biological) and Toxin Weapons and on their Destruction of 1975 calls upon States Parties to prevent the development, acquisition, or retention of biological war materiel and delivery systems for such substances within their own territories, and to implement the destruction of such inventories. Article IV's prevention measures also include the barring of the citizens and residents of States Parties from developing or retaining these inventories. As a step towards implementing the provisions or Article IV into US policy, and as an impetus for other states to adopt Article IV's provisions, the US Senate held hearings on the previously-mentioned S. 993, legislation that had been proposed as the additional Chapter 10 to Title 18 of the United States Code.

Section 175 of S. 993 stipulated that

(a) Whoever knowingly develops, produces, stockpiles, acquires, retains or possesses any biological agent, toxin, or delivery system for use as a weapon, or knowingly assists a foreign state or any organization to do so, shall be fined under this title or imprisoned for life or any terms of years, or both. There is extraterritorial Federal jurisdiction over an offense under this section committed by or against a national of the United States.

(b) For purposes of this section, the term 'for use as a weapon' does not include the development, production, transfer, acquisition, retention or possession of any biological agent, toxin, or delivery system for prophylactic, protective, or other peaceful purposes (US Senate, 1989: 8)

Section 178 of S. 993 defined a delivery implement as "any apparatus, equipment, device or means of delivery specifically designed to deliver or disseminate a biological agent, toxin or vector"(US Senate, 1989: 9). The term 'vector' referred to a living organism capable of carrying a biological agent or toxin to a host (US Senate, 1989: 9).

Witnesses who testified in favor of the S. 993 at the hearing of November, 1986, did so for various reasons. Ambassador Thomas Graham, Jr., then General Counsel of the Arms Control and Disarmament Agency (ACDA), noted the marked global growth in the field of biotechnology, both applied and theoretical, and the corresponding growth in the number of states interested in obtaining biological weapons. Dr. Barbara Hatch Rosenberg, then a microbiologist at the Memorial-Sloan Kettering Cancer Center, testified that if S. 993 became law, it would strengthen the US's negotiating position with the Soviet Union on chemical weapons. Ronald Noble, the Deputy Assistant Attorney General for the Criminal Division of the US. Department of Justice, remarked that the enactment of S. 993 would render liable to prosecution those who illegitimately developed, acquired, retained or disseminated biological weapons and their delivery systems prior to actual use, as well as after the fact (U.S. Senate 1989: 44, 52 \&78).

Congress adopted S. 993 as Public Law No. 101-298 on May 22, 1990. However, even though this Act became US law as an impetus for other states, as well as the US, to adopt the domestic enforcement provisions of Article IV of the Biological Weapons Convention as national policy, the Convention continued to lack formal compliance prescriptions. This omission meant that the Convention did not require States Parties to submit to overviews by an international organization, regular inspections of biological installations, control of exports of biological substances, or to declaring facilities for producing or disseminating biological agents.

\footnotetext{
${ }^{1}$ The instrument of international law to which Senator Church was referring was the Biological Weapons Convention of 1975, which had been signed in London, Washington and in 1972. The text of that Convention was one of the exhibits for the hearings of 1975 on the CIA's retention of biological weapons, entitled Intelligence Activities: Senate Resolution 21: Hearings Before the Select Committee to Study Governmental Operations with Respect to Intelligence Activities of the United States Senate. Ninety-Fourth Congress. First Session, Volume 1. "Unauthorized Storage of Toxic Agents," September 16, 17 and 18, 1975.
} 
In 1990, the year in which the US adopted Public Law No. 101-298, the only international law instrument concerning the policing of states in regard to biological weapons was A/RES/42/37. which the United Nations General Assembly had adopted in 1987.

This resolution empowered the United Nations Secretary General to initiate and conduct an investigation of a given UN member state after another member state had accused it of actually using biological or toxin weapons in violation of customary international law. The Secretary General was to devise guidelines for these investigations, and was to have at his or her disposal a roster of experts for the facilitation of such investigations. Under the United Nations Global Counter-Terrorism Strategy of 2006, the United Nations General Assembly encouraged the UN Secretary General both to update the guidelines for investigations, and the roster of experts. However, both A/RES/42/37 and the Global Counter-Terrorism Strategy limited the Secretary General's powers to addressing a State Party's actual use of biological weapons. The Secretary General was not, however, empowered to address the development, production and stockpiling of those weapons that the Biological Weapons Convention was meant to prohibit (Littlewood, 2018: 3-4).

For infraction of the Convention's Article I provisions, an accusatory state party could file a complaint with the United Nations Security Council, but any permanent member of the Council could, for any reason including a political one, veto resolutions calling for investigations of such complaints. Nor did the Convention, itself, grant the UN's Secretary General any independent, investigative powers. By contrast, the Convention on the Prohibition of the Development, Production, Stockpiling and Use of Chemical Weapons and on their Destruction of 1993 was administered by the Organization for the Prohibition of Chemical Weapons, a body empowered to verify a State Party's compliance (Schmelzer. 2013: 9-10\& 72).

\subsection{Transparency and Compliance}

The very nature of biological weapons presented some thorny problems regarding the transparency and compliance issue. In particular, these difficulties arose during the negotiations that the Ad Hoc Group of Governmental Experts (see below) was conducting in 1997 concerning the drafting of a transparency and compliance protocol which would accompany the Biological Weapons Convention. Several specific factors impeded accurate monitoring of the production of biological agents within a state, and the distinction between peacetime and militarily-oriented development and retention of these agents.

The first impediment to transparency and monitoring was the small quantity of most biological agents that a producer needed for significant weaponization. The second was the dual-use nature of biological agents. Even the deadliest of these substances played a vital role in the development of vaccines, and of other peacetime products as well (Rissanen, 2003).Thirdly, in order to develop its own defenses against germ warfare, a state had to develop its own biological research facilities. This research usually entailed that state's use of materials and technologies similar to those of states developing offensive germ warfare agents. Fourthly, any state engaged in biological research, offensive or peaceful, would have to do so under a substantial degree of secrecy (Schmelzer, 2013: 70). The final difficulty that was the speed with which biological weapons could be produced or destroyed. This factor called into question the effectiveness of short-notice inspections (Rissanen, 2003).

During the negotiations for the formulation of the provisions of the Biological Weapons Convention itself, which actually began before the promulgation of President Nixon's 1969 Executive Order, both the US and the Soviet Union had taken positions opposing strong compliance measures. The US expressed general skepticism about the potential effectiveness of international transparency measures and compliance procedures (Findley, 2009), and argued that multilateral compliance measures were likely to be intrusive, and would, consequently, compromise US military and commercial secrets. The USSR, on its part, presented similar grounds for objection, not wanting to jeopardize its own biological weapons development program. According to some Soviet defectors of subsequent years, the USSR had been continuing this program even after signing the 1975Convention (Schmelzer, 2013, p. 62).

Because so many countries were continuing to develop biological weapons even after they had signed the 1972 Convention (these states included apartheid South Africa as well as the USSR, and as discussed earlier, the US's CIA had been retaining biological weapons as well), the UN held a series of review conferences aimed at tackling the issue of enforcing the Convention. The First Review Conference took place in 1980, and its central discussion theme was the attachment of an enforcement protocol to the Convention. In its Final Declaration, this Review Conference encouraged States Parties to submit voluntary declarations outlining previous and present possession of equipment and agents that the Convention prohibited; measures taken either to destroy these items or to divert them towards peacetime uses; and national legislation enacted ensuring adherence to the Convention within states (Rissanen, 2003).

The issue of compliance with the Convention took on new dimensions at the Third Review Conference, in 1991 because the development of genetic engineering had now made it possible for laboratories to design deadlier microorganisms, and because biotechnology in general had improved. At the same time, the progress that 
multilateral negotiators were making in completing the Chemical Weapons Convention, which included a strict compliance regimen for States Parties, revived the hope among participants in the review conferences that they could similarly strengthen the Biological Weapons Convention (Schmelzer, 2013: 73-78)

\subsubsection{The Ad Hoc Group and the Composite Text.}

At the Third Review Conference, the States Parties to the Biological Weapons Convention established the Ad Hoc Group of Governmental Exports, and charged it with the task of identifying measures by which to determine if a State Party had been producing, acquiring, retaining or stockpiling quantities and types of biological material unjustified by prophylactic, preventative or other peacetime needs, or means for disseminating this material (Schmelzer: 2013: 81-82). At a special conference that the States Parties convened in 1994, they charged the Ad Hoc Group with including these transparency-ensuring measures in a legally-binding compliance protocol. The protocol was to provide the formulation of a list specifying the banned materials and equipment upon which the Convention was focusing, and methods for implementing Article X of the Convention (Rissanen, 2003). As stated above, this Article had stipulated that States Parties were to share technological information and to assist each other regarding the peacetime use of biological agents. Among its compliance measures, the protocol was to prescribe inspections of biological facilities where necessary, but these inspections were not to compromise a State Party's legitimate security and commercial secret concerns.(Schmelzer, 2013: 82).

The change in US Presidential administrations that took place between the Third Review Conference in 1991 and the Fourth Review Conference of 1996 seemed to indicate a US position that had become more favorable to the idea of adopting a transparency protocol to accompany the Biological Weapons Convention. Where the Administration of George H.W. Bush had opposed on-site inspections and had supported only those external investigations that were responding to serious allegations of violations and pronounced outbreaks of disease, the Clinton Administration, which took office in 1993, initially appeared to favor clarification visits and more routine facility investigations. However, President Clinton's administration contained many officials who either did not favor, or did not prioritize, a multilateral transparency protocol. Consequently, the US did not present a decisive position on this matter at the Ad Hoc Group's meetings of 1995 and 1996. (Schmelzer, 2013: 83-84).

Within the US, the Pentagon, the US Department of Commerce, other US Government bodies, and the US's pharmaceutical industry were forces that strongly opposed the Ad Hoc Group's formulation of a transparency protocol. The Pentagon opposed such a protocol on the grounds that multilateral inspection and compliance regimens might compromise Washington's own biological weapons defense program, which developed vaccines and protective equipment, and analyzed biological warfare threats to the US (Charatan, 2001: 1326). Other US officials stressed the difficulties inherent in compliance verification. These officials argued that offensive biological weapons were easy to hide, and that ordinary pharmaceuticals plants could easily produce them in weaponization quantities (Klotz, 2019).

The Department of Commerce, for its part, was representing the interests of large US pharmaceutical companies by supporting their proprietary rights to their findings and trade secrets (Charatan, 2001: 1326). These proprietary rights included special strains of bacteria which these companies were developing for improving antibiotics and for other manufacturing processes. There was also the fear that during a visit or inspection, employees might inadvertently divulge proprietary information (Klotz, 2019).

Large, US-based pharmaceutical concerns accounted for 80 per cent of global research and development in the field of biotechnology as of 1995, and it was also true that the largest number of these biotechnology facilities were located in the US. These facts indicated that most visits and inspection conducted under a transparency protocol would take place on US soil.

Washington, therefore, did not favor provisions requiring States Parties to the Convention to file declarations providing details about their biological facilities, and to submit to visits and inspections. Nor was the US willing to provide twenty per cent of a transparency body's budget under the protocol in order to finance inspections and visits that would mainly involve its own facilities (Schmelzer, 2013:85). Some US officials also feared that teams visiting or inspecting US biodefense installations under the protocol might be agents of foreign powers seeking classified information (Klotz, 2019).

The US also differed with its Western allies in terms of how States Parties were to affirm or challenge a violation investigation. While most of these Western states favored requiring a three-fourths majority vote among the States Parties to stop an investigation, the US wanted a procedure which required a simple majority vote for the approval of an investigation The Ad Hoc Group adopted Washington's approach, despite the fact that it was likely to make an investigation of a violator more difficult (Schmelzer, 2013:85-86). 
The Ad Hoc Group drafted a Composite Text of the transparency protocol in 2001. In brief, the draft called for the establishment of the Organization for the Prohibition of Biological Weapons, which was to monitor the implementation of both the Convention and the transparency protocol. This Organization was to be empowered to evaluate the initial and annual declarations that each State Party to the Convention was to submit about all of its biological research and development activities.

A State Party's initial declaration was to describe the development its biotechnology industry since 1946, and each subsequent annual one was to cover all of that State Party's new activities concerning biological agents and delivery systems for the previous calendar year.

The Organization was also to have the power to conduct random and follow-up visits to States Parties' facilities pertaining to storage, production and dissemination of biological agents. These visits were to be permissible at the Organization's own initiative, or as a result of one State Party's allegation that another was contravening the Biological Weapons Convention. A given State Party was also to have the right to submit a request to the Organization for a field or facility investigation within a second state party in response to a serious outbreak of disease affecting populations of humans, animals or plants. However, the protocol's Composite Textemphasized that the accusing State Party would be required to substantiate its request for the investigation with detailed evidence that the outbreak had been the result of infraction of the Convention, rather than the result of natural causes. The Organization was to conduct both visits and investigations within the framework of negotiated managed access, under which the Organization and the State Party in question would agree upon the extent to which the Organization's visiting or investigation teams would have access to biological facilities or areas where there had been outbreaks of disease. While States Parties being visited or investigated were to retain the right to protect their confidential national security and commercial data, they were also to furnish the Organization's visiting or investigation teams with agreed upon information about biological activity.

Under the draft of the protocol, States Parties were also to review, amend or establish legislation or administrative policies that would ensure that biological agents and their delivery systems were transferred to recipients intending to use them for prophylactic, protective, or for other peaceful purposes only. Safeguards towards this objective could include requiring the recipient to certify the end-use purpose of the requested import, or mandating a written pledge from the importer that the transferred items would not be re-exported. The protocol's Composite Text was also to empower States Parties to the Biological Weapons Convention to place cases of serious infraction of, or damage to, the purposes of the Convention before the United Nations General Assembly, or the United Nations Security Council. States Parties could also collectively resort to other measures that international law provided regarding infractions of the Convention. ${ }^{2}$

While most of the States Parties approved these provisions (Rissanen, 2003), the US rejected the Composite Draft in 2001,during the d Hoc Group's final session. Washington rejected the Composite Draft on the following grounds: 1) Washington, under the George W. Bush Administration, continued to doubt that the transparency protocol would ensure compliance with the Biological Weapons Convention; and 2) many US officials, and those of the pharmaceutical industry, continued to maintain that the protocol would compromise national security and confidential business information. As a result of the US's rejection of the Protocol's Composite Text, negotiations concerning it collapsed. Shortly after the George W. Bush Administration had appointed him Under-Secretary of State for International Security, John Bolton demanded that the Ad Hoc Group terminate its mandate for negotiating the Biological Weapons Convention's transparency protocol. Nordid the Obama Administration, which took office in 2009, reverse the decision of its predecessor to reject the Composite Text (Schmelzer, 2013: 87-88, 90 \& 97).

The Ad Hoc group's failure to devise a compliance regimen for the Biological Weapons Convention left the international community with the transparency guidelines provided in Articles V, VI, and X of the Convention. Together, these Articles urge States Parties to cooperate, among themselves, or in conjunction with the United Nations, in resolving instances of non-compliance with the Convention, and in the exchange of technological information that would help states parties gear inventories of biological substances with weaponization potential towards peacetime uses. Article VI, as mentioned previously, allows States Parties to file well-substantiated reports to the UN Security Council regarding other States Parties' infractions of the Convention, but, as discussed before, Security Council investigative resolutions remain subject to vetoes by those permanent members of the Security Council that have political interests in doing so.

\footnotetext{
${ }^{2}$ See Ad Hoc Group. Protocol to the Prohibition of the Development, Production and Stockpiling of Bacteriological (Biological)and Toxin Weapons and on their Destruction. BWC/AD HOC GROUP/CRP.8. (Technically corrected version). 30 May, 2001.
} 


\section{Unilateralism, Multilateralism, and Policy Concerning Weapons of Mass Destruction}

Caramay Schmelzer considers the George W. Bush Administration's rejection of the Biological Weapons Convention's transparency and compliance protocol a manifestation of two related outlooks that have been fundamental principles of US foreign policy since the end of World War II. These principles are Manifest Destiny and American Exceptionalism. Schmelzer calls Manifest Destiny, as applied to Washington's post-World War II foreign policy, the view that the US has a special moral mission to fulfill in the rest of the world.

American Exceptionalism maintains that because of this special mission, it is American military and economic power that guarantees a law-abiding world system, rather than the multilateralism embodied in such instruments as the Biological Weapons Convention. ${ }^{3}$

By contrast, David P. Fidler, Professor of Law at the Indiana University School of Law at Bloomington, argues that the second Bush Administration's action regarding the Biological Weapons Convention's compliance protocol reflected the changing realities within the world system following the end of the Cold War. He argues that to the US, these developments necessitated a change in the approach to, and in the application of, international law. The end of the bi-polar world system was the main factor that ushered in the US's revised look at international law, for under the bi-polar system, both the US and the Soviet Union had been bound by the principle of Mutually Assured Destruction (MAD), and both superpowers were committed to non-proliferation of nuclear weapons. With the end of the bi-polar system after 1991, it looked to the US as if a series of new state and non-state actors would inherit parts of the former Soviet nuclear arsenal. The breakup of the Soviet Union and its metamorphosis into the Commonwealth of Independent States meant that key nuclear and biological agents that had formerly been under Soviet control could now find their ways into the arsenals of some of these new states and their allies, and even into the hands of non-state actors. This fluid situation also increased the possibility of theft of these biological agents, and their transference into new hands via the emigration of former Soviet scientists (Fidler, 2004: 62-63\& $62 \mathrm{n}$. 91).

Another factor that made the spread of biological weapons an alarming possibility during the post-Cold War years was the general development of genomics and biotechnology, and the facilitated diffusion of such knowledge worldwide. In addition, the skills, information, and precursor materials required for the development of nuclear, chemical, or biological weapons were readily available because they could be used for peaceful purposes, as well as military ones. The dual-use potential of both the knowledge and material that contributed to the development of all weapons of mass destruction compromised the effectiveness of international treaties as regulators of proliferation (Fidler, 2004: 66).

Hence, after 2001, the US emphasized unilateral actions as self-defense against the proliferation of biological weapons and other weapons of mass destruction, and turned to international law doctrines that justified this approach. The international law provision under which the George W. Bush Administration justified its unilateral approach to defending the US against an adversary's nuclear, chemical or biological weapons was Article 51 of the United Nations Charter, which grants United Nations member states the right to individual or collective selfdefense against armed attacks. The unilateralist counter-proliferation principles that the US came to emphasize during in the post-Cold War era are embodied in the George W. Bush Administration's National Strategy to Combat Weapons of Mass Destruction. In this document, the White House emphasized the role that the US's unilateral military, intelligence, and domestic law-enforcement capabilities would play in preventing material, technology and expertise pertaining to weapons of mass destruction from reaching hostile state or non-state actors.

The George W. Bush Administration's national strategy document further declared the US's right to use "overwhelming force" in response to any state's or organization's use of weapons of mass destruction against the US itself, US troops deployed abroad, or any of Washington's friends and allies among states. This overwhelming force could include the use of conventional weapons, nuclear power, domestic and friendly foreign intelligence agencies and domestic law enforcement (The White House, 2002: 2-4). Nor did the National Strategy document preclude the US's use of nuclear power against non-nuclear states. Overwhelming force was also to be available for purposes of interdiction, or the prevention of the transfer of weapons of mass destruction to hostile states or to hostile non-state actors (Alvarez-Verdugo, 2005: 125).

The preemptive capabilities that the White House document was prescribing included the ability to detect and destroy any adversary's weapons of mass destruction before they reached their targets. In addition, the White House document stated that, in a post-conflict situation, US forces would detect and destroy any adversary's

\footnotetext{
${ }^{3}$ For Schmelzer's detailed treatment of the concepts of Manifest Destiny and American Exceptionalism,see Chapters 1 and 3 of CaramaySchmelzer, Ambivalent Multilateralism: The United States and the Biological Weapons Protocol. M.A. Thesis, American Studies. Utrecht University, 1 December, 2013. Utrecht, Netherlands.
} 
residual inventory of nuclear, chemical or biological weapons, so that future adversaries could not develop or obtain them(The White House, 2002: 2-4).

The White House document also included non-proliferation diplomacy as a means for dissuading supplier states from allowing actors hostile to the US to obtain weapons of mass destruction, and of persuading states that were developing weapons of mass destruction to end their WMD programs. This diplomacy mainly entailedthe building of coalitions in support of the US's anti-proliferation objectives.

Significantly, the US's anti proliferation objectives, as stated in the Bush Administration's National Strategy document, did not include prescriptions for co-responsibility between the US and other actors in reducing proliferation. The document did not, for instance, mention US disarmament commitments, or self-constraint measures for Washington to take regarding nuclear weapons (Alvarez-Verdugo, 2005: 127-128)

In contrast to unilateralism that the US's National Strategy to Combat Weapons of Mass Destruction featured, the European Union Strategy Against Proliferation of Weapons of Mass Destruction of 2003 emphasized multilateralism as the best means for combating the spread of these weapons. The multilateral nature of the $E U$ Strategy's recommendations stemmed first from the fact that the EU, itself a multilateral organization, had formulated and promulgated this document. Like the US, the EU aimed to curtail and stop the local and regional threats that uncontrolled proliferation of nuclear, chemical and biological weapons posed, and the EU Strategy document called upon all EU member states to cooperate in combating these threats. Potentially endangered European interests that the document mentioned included the EU states themselves, and also expatriate communities located in states that had initiated weapons of mass destruction programs; troops stationed or deployed in these states; and economic interests outside of Europe, such as investments, export markets and natural resources. At the same time, the document stressed that the proliferation of weapons of mass destruction was a threat to international peace and security in general, and not only to the EU. (Council of the European Union, 2003: $2 \& 4)$.

Fundamental elements of the multilateralism that the EU Strategy document embodied included the call for implementation and strengthening of all multilateral non-proliferation treaties; support of multilateral institutions charged with verifying compliance with the non-proliferation treaties; the strengthening of verification instruments; the criminalization of acts by states resulting in unlawful development and acquisition of weapons of mass destruction within their boundaries; internationally-coordinated export controls (Council of the European Union, 2003: 5-6); and technical and financial assistance from the EU to states that were having difficulty implementing international agreements such as the Biological Weapons Convention and the Chemical Weapons Convention. Since the Biological Weapons Convention did not have a formal set of provisions for the monitoring of compliance with its prescriptions, the EU Strategy Document advocated the establishment of a group of experts who would guide states parties towards compliance with the Convention. EU multilateralism was also to include a dialogue between EU and US industries which would deepen awareness of the connection between industries and the development of biological agents and other potential weapons of mass destruction (Alvarez-Verdugo, 2005: 130$131 \& 132)$.

While these measures were to constitute the EU's first line of defense against weapons of mass destruction, the EU could resort to more coercive measures under Chapter VII of the United Nations Charter if these first steps failed. The more coercive measures that the UN Charter allowed included sanctions, selective or global interception of shipments, and, if necessary, the use of force. The United Nations Security Council was serve as the body that implemented these measures (Council of the European Union, 2003:5-6).

However, while outlining the actions that EU member states were to take in response to the spread of nuclear, chemical and biological weapons, the EU Strategy document also stressed the importance of addressing factors that might motivate states and non-state actors to obtain and develop these weapons. Specifically, the document advocated the seeking of stability through the fostering of political solutions to states' security problems. In particular, the EU sought to foster dialogue with states voicing these security concerns, addressing these concerns while encouraging these states to renounce technology for the development of weapons of mass destruction (Council of the European Union, 2003: 7) Other contributions to stability that the EU Strategy document advocated for the European Union was development assistance to, and reduction of poverty within, internally unstable states, and the promotion of human rights (Alvarez-Verdugo, 2005:129)

In the specific case of biological weapons, the EU Strategy document viewed proliferation as something that had become increasingly difficult to monitor and control. Improved global, scientific expertise about developing these weapons, along with their delivery systems, was increasing the possibility of harmful application of the dual-use nature of these substances. Moreover, it was difficult to trace the signature of biological weapons, and to contain their damage because of diversity among the substances themselves, and among their targets, which could be human, plant or animal life. Hence, the EU Strategy document called for the universalization of the Biological 
Weapons Convention, and the institution of a binding ban on biological weapons within international law at large. (Council of the European Union, 2003:4\& 6).

Despite its contrasts with the George W. Bush Administration's National Strategy document of 2002, the European Union's Strategy against Proliferation of Weapons of Mass Destruction of 2003, itself, was an indicator of the Union's increased focus on inducing compliance with international accords among recalcitrant proliferation states, rather than on sole reliance upon the adoption of multilateral agreements. The EU's Strategy document had included provisions outlining coercive measures that the EU could employ against non-compliant states, whereas previously, its members, and particularly Germany, had shunned such measures.

Also during 2003, the EU had decided to include non-proliferation clauses within each of its Trade and Cooperation Agreements (TCAs) with external states, as the EU's approach to Iran demonstrated. The European Union had previously differed markedly with the United States regarding Iran, favoring engagement and avoiding the linkage of political and economic relations to Iran's development of nuclear capabilities, but towards the end of 2003, the EU made its Trade and Cooperation Agreement with Iran contingent upon Teheran's submission to more intrusive International Atomic Energy Agency (IAEA) inspections of its nuclear facilities.(Kaye, 2004: 33-34).

Consequently, the European Union and the United States were able to emerge from their Summit of 2004 with a Declaration on the Nonproliferation of Weapons of Mass Destruction. Under this Declaration, the EU and the United States agreed to support efforts to interdict shipments of these weapons, and to cooperate in their uses of intelligence and law enforcement against proliferation networks. Export controls of these weapons and of delivery devices were to be strengthened, and fortified by criminal sanctions. The EU and Washington also agreed to strengthen the powers of the International Atomic Energy Agency (IAEA) through the implementation of the Agency's Additional Protocol for monitoring safeguards and for verifying adherence to the Non-Proliferation Treaty. Washington and the EU member states also resolved to cooperate in order to safeguard the security of radioactive materials and to prevent their misuse (The White House, 2004).

Concerning biological weapons in particular, the 2004 Declaration on the Nonproliferation of Weapons of Mass Destruction affirmed that the United States and the EU would cooperate to strengthen their capabilities of preventing and responding to bioterrorism, and would implement Security Council Resolution 1540 (The White House, 2004). Security Council Resolution 1540 stipulated that UN member states were to enforce controls against actors within their own boundaries engaged in obtaining or developing biological weapons and their delivery systems, along with chemical and nuclear agents. Resolution 1540 also enjoined UN member states to develop accurate measurements of inventories of these items, maintain their adequate physical protection, control their illicit export and trafficking, and promote the universal adoption, implementation, and where necessary, the strengthening of all multilateral treaties aimed at preventing the spread of biological, nuclear and chemical weapons. Finally, UN member states were to see to it that these items and their delivery systems did not reach the inventories of non-state actors (United Nations Security Council, 2004: 2-3).

Despite the demise of the Ad Hoc Group's Composite Text for the compliance protocol in 2001, States parties to the Biological Weapons Convention continued to find multilateralism useful, as shown in the Biological Weapons Convention's Sixth Review Conference's establishment of the Implementation Support Unit (ISU) in 2006.The ISU was established to facilitate the implementation and universalization of the Biological Weapons Convention, but it did not resurrect the prescriptions of the Ad Hoc Group's Composite Text. The ISU's focus was not on bringing about compliance with the Convention through centralized requirements, but, rather, on encouraging States Parties to abide by the Convention through the adoption of state policies, as outlined in Article IV of that agreement In order to achieve this objective, the ISU was designed to play a central role in strengthening Confidence Building Measures (CBMs) among the Convention's States Parties. Therefore, the ISU was not empowered to conduct inspections of non-compliant states or visits to biological facilities.

Participants in the Biological Weapons Convention's Review Conferences had actually been outlining CBMs for States Parties to adopt prior to 2006. In fact, most of these measures had been outlined as early as 1986 and 1991, the years during which the Second and Third Review Conferences were respectively held. The CBMs that the ISU was to encourage states to adopt included the exchange of information among themselves about both recent and past developments in their biological expertise and biotechnological industries. States Parties were urged to give militarily-oriented biological industries, offensive or defensive, thorough coverage in the CBM declarations they submitted, and to declare the workings and locations of vaccine production facilities. CBM declarations were also to include descriptions of the activities and locations of research centers and laboratories and were to feature information on safety standards that these facilities met, and the extent to which they were handling dangerous agents. States were also encouraged to exchange information about unnatural outbreaks of infectious diseases, as well as illnesses caused by toxins. These reports were to describe the specific ways in which outbreaks that 
occurred deviated from typical outbreak patterns. Details covered were to include the disease's nature and development, the time and location of the outbreak, and the number of cases. (Pearson, 2016:25).

CBMs that states, the scientific community, and academic organizations could undertake included the publication of the results of biological research in journals generally available within States Parties, and facilitation of the use of these findings towards purposes that the Biological Weapons Convention permitted. Scientists from different states were encouraged to share the results of biological research that were related to the provisions of the Convention, and to engage in joint research projects under mutual agreement (Pearson, 2016: 25). In their CBM declarations, states parties were encouraged to cover legislation, regulations, and other measures that their governments had taken towards the implementation of the Biological Weapons Convention.

Reporting States Parties could also obtain forms for stating that they had nothing, or nothing new to declare regarding developments in the life sciences or in biological industries. The Seventh Review Conference, held in 2011, encouraged States Parties to submit their CBM declarations annually (Pearson, 2016: 25).

In order to strengthen the adoption of CBMs among states, the ISU was first to facilitate activities that would encourage States Parties towards participation in the CBM process. In carrying out this encouragement policy, the ISU was to distribute among states parties CBM declarations it had already received as examples. The ISU was also to inform States Parties when their annual CBM declarations fell due. In addition, at each Meeting of States Parties to the Biological Weapons Convention, the ISU was to compile and distribute collected data on CBMs that States Parties had thus far adopted. Another of the ISU's tasks were maintenance of a website for this data and serving as an information clearing house which would assist states parties in preparing CBM documents. With these duties came such administrative tasks as the facilitation of communication among States Parties and international organizations, and engendering contact between States Parties and scientific, academic, and non-governmental organizations (NGOS). The ISU was generally to be a center that states used for the sharing of information about the Biological Weapons Convention, and was to support States Parties in arriving at their own policy decisions about implementing the Convention's provisions (United Nations, 2006: 20).

In encouraging States Parties to implement the Convention through government measures, and in urging other national governments to sign and ratify the Convention, the ISU hosted workshops and seminars on biological weapons, developments in the life sciences, and on the Convention itself. The ISU also participated in similar programs that national governments, regional organizations, the scientific community, the private sector, and academia sponsored. National governments, and regional or international organizations could also turn to the ISU for information about the Biological Weapons Convention itself and assistance regarding the specifics of implementation plans, and the building of $\mathrm{CBMs}^{4}$

\section{Conclusion}

In recent decades, no belligerent has used biological agents in warfare. Yet biological weapons remain a source of global fear. This fear stems from the particularly gruesome images biological warfare calls to mind. It is easy, in thinking of biological warfare, to imagine rotting corpses thrown over walls during a siege, or animal carcasses thrown down wells or into rivers. It is also easy to imagine massive numbers of civilians dying excruciatingly horrible deaths from plague or anthrax.

One factor that makes biological weapons so terrifying is the ease and speed with which biological agents and toxins can be weaponized, on account of their portability, and potential strength in relation to quantitysize. It is possible to weaponize most bacteria, protozoans, viruses, fungi and toxins in very small quantities. It is also frequently difficult to trace the signatures of these agents if they are used in warfare, given their diversity and since they can affect plants, animals or humans.

In addition, since bacteria, protozoans and viruses are monocellular living things, they reproduce and mutate with frightening speed. This means that once a belligerent disseminates them, it has little control of the targets they attack. Moreover, modern biotechnology can create milder or particularly deadly strains of these organisms according to motivation. Yet, despite the terrifying attributes that biological weapons potentially have, the Biological Weapons Convention, which is currently the most comprehensive multilateral instrument aimed at controlling the proliferation of biological war materiel, still lacks enforcement provisions.

It is true that it is often difficult to discern the point at which the beneficial development of inventories of biological agents ends and weaponization begins. This difficulty is due to the dual nature of most biological agents. They are vital for the development of vaccines, and the testing of antibiotics and antidotes. In addition, facilities that are

\footnotetext{
${ }^{4}$ See United Nations Organization at Geneva, all Annual Reports of the Implementation Support Unit of the Biological Weapons Convention,2007-2019(BWC/MSP/2007/3)-(BWC/MSP/2019/4). https://www.unog.ch/80256EE600585943/(httpPages)/16C37624830EDAE5C12572BC0044DFC1?OpenDocument .
} 
actually producing biological weapons are often difficult to distinguish from those that are using biological agents for peaceful purposes. It is fairly easy for pharmaceuticals plants that actually are producing biological weapons to conceal their activities on short notice. It is also relatively easy for a peacetime pharmaceuticals plant to convert its functions to the production of germ warfare materiel.

However, the factor that most impedes implementation of Article I of the Biological Weapons Convention is the fact that the possession of germ warfare inventories remains a highly politicized issue. The arguments surrounding the demise of the Ad Hoc Group's Composite Text for the compliance protocol in 2001, for instance, underscore the reluctance of both superpowers to disclose fully the activities of their biotechnological industries.

It is also true that while the UN Secretary General has the power to investigate a UN member state's alleged use of biological weapons, he or she cannot investigate acquisitions, development, retained inventories, or stockpiles of these agents as such. Although a State Party to the Biological Weapons Convention may submit requests for such investigations to the UN Security Council, permanent members of the Council are empowered to shield allies and client states by vetoing resolutions calling for such investigations.

The Confidence Building Measures (CBMs) that the Review Conferences of the Biological Weapons Convention have established are important steps towards introducing to national governments, international groups, the scientific community, and academic groups the merits of cooperation and sharing concerning biological research. It is the political factor, though, that really impedes implementation of Article I of the Convention.

\section{Sources}

Ad Hoc Group. (30 May, 2001).Protocol to the Prohibition of the Development, Production and Stockpiling of Bacteriological (Biological)and Toxin Weapons and on their Destruction(BWC/AD HOC GROUP/CRP.8). United Nations Office at Geneva.(Technically corrected version). Retrievd from https://www.unog.ch/bwcdocuments/2001-04-AHG23/BWC_AHG_CRP.08.pdf.

Alvarez-Verdugo, Milagros. (2005). Comparing U.S. and E.U. Strategies Against Weapons of Mass Destruction: Some Legal Consequences.Annual Survey of International and Comparative Law, 11(1)Article 7. 119-140. Retrieved fromhttps://digitalcommons.law.ggu.edu/cgi/viewcontent.cgi? article=1095\&context=annlsurvey.

Charatan, Fred.(June 2, 2001). US Rejects Biological Weapons Convention Protocol. British Medical Journal, 322(7298). 1326. Retrieved from https://www.ncbi.nlm.nih.gov/pmc/articles/PMC1173329/.

Council of the European Union. (10 December, 2003).EU Strategy Against the Proliferation of Weapons of Mass Destruction..(Doc.No.15708/03,Annex).European Union. Retrieved from https://register.consilium.europa.eu/doc/srv?l=EN\&f=ST\%2015708\%202003\%20INIT

Falk, Richard A.(1986).Inhibiting Reliance of Biological Weaponry: The Role and Relevance of International Law.American University International Law Reviewl(1)Article 3. 17-34. Retrieved from https://digitalcommons.wcl.american.edu/cgi/viewcontent.cgi?article=1643\&context=auilr

Fidler, David P. (2004). International Law and Weapons of Mass Destruction: End of the Arms Control Approach?Duke Journal of Comparative \& International Law, 14(1/2). 39-88. Retrieved from .https://scholarship.law.duke.edu/cgi/viewcontent.cgi?article=1132\&context=djcil

Findley, Trevor. (2006).Verification and the BWC: Last Gasp or Signs of Life?Arms ControlToday. 36 (September, 2006).Retrieved from https://www.armscontrol.org/act/2006-09/features/verification-bwc-last-gasp-signslife.

Graham, Thomas Jr. (March 29, 2002).Biological Weapons and International Law, Science Magazine, 295, (5564). 2325. Editorial. https://DOI: 10.1126/science.295.5564.2325.

Implementation Support Unit. (2007-2019). All Annual Reports, 2007-2019.(BWC/MSP/2007/3)(BWC/MSP/2019/4).United Nations Office at Geneva. Implementation Support Unit of the Biological Weapons Convention. Retrieved from https://www.unog.ch/80256EE600585943/(httpPages)/16C37624830EDAE5C12572BC0044DFC1?Open Document

Kaye, Dalia Dassa. (2004). Mind the Gap: The United States, Europe and the Middle East. Netherlands Institute of International Relations Clingendael. Retrieved from https://www.clingendael.org/sites/default/files/pdfs/20040700_cli_ess_kaye.pdf.

Klotz, Lynn C. (November 15, 2019).The Biological Weapons Protocol Should Be Revisited. Bulletin of the Atomic Scientists. Retrieved from https://thebulletin.org/2019/11/the-biological-weapons-conventionprotocol-should-be-revisited/\#.

League of Nations. (1925)Protocol for the Prohibition of the Use in War of Asphyxiating, Poisonous, or Other Gases, and of Bacteriological Methods of Warfare. Retrieved from United Nations, Office of Disarmament Affairs. Retrieved from https://www.un.org/disarmament/wmd/bio/1925-geneva-protocol/. 
Littlewood, Jez. (2018). Revisiting BWC Verification: Investigations. Policy Brief 6 of 7. King's College, London. Retrieved from http://www.filippalentzos.com/wp-content/uploads/2018/08/Policy-Brief-6.pdf.

Pearson, Graham S. (2016).Time for structural change to make the Biological and Toxin Weapons Convention more effective. Global Security, Health Science and Policy: An Open Access Journal(1). 23-38. Retrieved from https://www.tandfonline.com/doi/full/10.1080/23779497.2016.1213135.

Rissanen, Jenni. (March 1, 2003). The Biological Weapons Convention.Nuclear threat Initiative.Retieved from https://www.nti.org/analysis/articles/biological-weapons-convention/.

Schmelzer,Caramay. (2013). Ambivalent Multilateralism: The United States and the Biological Weapons Protocol.Master's Thesis, American Studies. Utrecht University.

United Nations. (1972). Convention on the Prohibition of the Development, Production, and Stockpiling of Bacteriological (Biological) and Toxin Weapons and on their Destruction. Office for DisarmamentAffairs. Retrieved from http://disarmament.un.org/treaties/t/bwc/text. . (2006). Sixth Annual Conference of the States Parties to the Convention on the Prohibition of the Development, Production and Stockpiling of Bacteriological (Biological) and Toxin Weapons and on their Destruction. BWC/CONF.VI/6.Biological Weapons Convention. Final Document. Retrieved from https://undocs.org/en/BWC/CONF.VI/6.

United Nations Security Council. (28 April, 2004). Resolution 1540. S/RES/1540 (2004). 4956 ${ }^{\text {th }}$ Meeting. https://undocs.org/S/RES/1540(2004.

United States Department of State. (September 25, 2002). Protocol for the Prohibition of the Use in War of Asphyxiating, Poisonous, or Other Gases, and of Bacteriological Methods of Warfare: Narrative. Bureau of International Security and Nonproliferation. Retrieved from https://2009-2017.state.gov/t/isn/4784.htm.

United States Senate. (September 16-18, 1975).Hearings Before the Select Committee to Study Governmental Operations with Respect to Intelligence Activities of the United States Senate. Unauthorized Storage of Toxic Agents. Ninety-Fourth Congress. First Session, Volume 1. Retrieved from https://www.intelligence.senate.gov/sites/default/files/94intelligence_activities_I.pdf.

.(May 16, 1989). A Bill to Implement the Convention on the Prohibition of the, Development, Production and Stockpiling of Bacteriological (Biological) and Toxin Weapons and Their Destruction, by prohibiting certain conduct relating to biological weapons, and for other purposes.S.993,101 ${ }^{\text {st }}$ Congress, $1^{\text {st }}$ Session. Retrieved from https://babel.hathitrust.org/cgi/pt?id=pst.000016110335\&view=1up\&seq=134.

(July 26, 1989).The Biological Weapons Anti-Terrorism Act of 1989: Hearing Before Committee on the Judiciary, United States Senate., One Hundred First Congress, First Session, on S.993.Senate. Hearing. Serial No. J-101-32. 101-416. Retrieved from https://babel.hathitrust.org/cgi/pt?id=pst.000016110335\&view=1up\&seq=1.

The White House. (2002). National Strategy to Combat Weapons of Mass Destruction. Retrieved from https://www.washingtonpost.com/wp-srv/nation/articles/nationalstrategywmd_Dec10.pdf. . (2004).Fact Sheet: U.S.-EU Summit: Declaration on the Nonproliferation of Weapons of Mass Destruction. Retrieved from https://georgewbush-whitehouse.archives.gov/news/releases/2004/06/20040626-11.html. 